\title{
PRODUCTION OF BITUMEN MODIFIED WITH LOW-MOLECULAR ORGANIC COMPOUNDS FROM PETROLEUM RESIDUES. 3. TAR MODIFIED WITH FORMALDEHYDE
}

\author{
Volodymyr Gunka ${ }^{1}$, Yuriy Prysiazhnyi ${ }^{1}$, Yurii Hrynchuk ${ }^{1}$, Iurii Sidun ${ }^{1}$, Yuriy Demchuk ${ }^{1,}$ \\ Olena Shyshchak ${ }^{1}$, Olha Poliak ${ }^{1}$, Michael Bratychak ${ }^{1, \bigotimes}$
}

https://doi.org/10.23939/chcht15.04.608

\begin{abstract}
The chemical modification of tar with formaldehyde as $37 \%$ aqueous solution has been studied in the presence of the catalysts. Hydrochloric acid, sulfuric acid, sodium hydroxide and acid tar were used as the catalysts. The effect of the catalyst nature and amount, as well as temperature, process time and initial components ratio on the softening point, penetration, brittle point and adhesion to crushed stone has been determined. The structure of the modified tars was confirmed by IR spectroscopy. The structural-group composition was determined. Arene-formaldehyde resins have been synthesized on the basis of toluene and modified tars using hydrochloric acid as a catalyst. The synthesized resins were characterized using IR spectroscopy. The chemistry of the tar modification with formaldehyde has been proposed.
\end{abstract}

Keywords: tar, formaldehyde, inorganic acid, acid tar, IR spectroscopy, crushed stone, softening point, penetration, brittle point, adhesion, arene-formaldehyde resins.

\section{Introduction}

Bitumen produced at the refineries does not always meet the demands set by the road construction $[1,2]$. To improve the bitumen operational characteristics, petroleum residues for bitumen production are modified via both physical and chemical methods [2].

Physical modification provides the introduction of various additives into the structure of petroleum residues. The additives improve the operational characteristics but remain unchanged the chemical structure. Depending on the nature additives are divided into elastomers (natural and synthetic rubbers, rubber crump), thermoelastoplasts

\footnotetext{
${ }^{1}$ Lviv Polytechnic National University

12, S.Bandery St., Lviv, 79013, Ukraine

mbratychak@gmail.com

(c) Gunka V., Prysiazhnyi Y., Hrynchuk Y., Sidun I., Demchuk Y.,

Shyshchak O., Poliak O., Bratychak M., 2021
}

(block-copolymers of butadiene and styrene of SBS type), thermosetting materials (epoxy, phenol-formaldehyde and other resins) and thermoplastics (polystyrene, polyethylene, Butanol NS, Viscoplast-S, petroleum resins, etc.) $[1,2]$.

Chemical modification of petroleum residues provides the change in their chemical structure due to the effect of modifiers on the mixture components in the presence of catalysts or initiators. Chemical modification is studied and used less if compared with physical modification. Nowadays for petroleum residues there is not generally accepted classification of chemical modification processes and types of chemical modifiers. Moreover, the developed industrial processes using chemical modification are actually absent, despite the possibility to achieve better operational performance of the resulting products [2].

In recent years the investigations regarding the development of new modifiers for petroleum residues have been carried out in Lviv Polytechnic National University [312]. On the basis of $C_{9}$ fraction, which is a by-product of hydrocarbon pyrolysis, the petroleum resins with functional groups were synthesized and investigated as additives for industrial bitumen, as well as in the processes of tar oxidation [3-6]. Wastes after coal carbonization were used to produce coumarone-indene resins with epoxy groups [11-12]. The introduction of mentioned resins into bitumen allows to improve its thermal and adhesive properties. The introduction of additives with peroxy or carboxy groups increases the adhesion properties of commercial bitumen by 2-2.5 times [7-9].

Phenol-formaldehyde resins with peroxy groups as additives not only increase bitumen heat resistance but participate in the formation of bitumen structure [10,11, 13].

Maleic anhydride was also studied as bitumen modifier [14]. The modification temperature was found to be $403 \mathrm{~K}$, modification time of $30 \mathrm{~min}$, amount of modifier $2 \mathrm{wt} \%$ relative to the initial bitumen. Such modification allows to increase bitumen adhesion. 
The usage of formaldehyde $(37 \%$ aqueous solution) as a modifier for petroleum residues is a new and interesting process, which is carried out in the medium of organic solvents in the presence of hydrochloric acid as a catalyst. Such organic solvents as toluene, $p$-xylene, $n$-octane and naphtha solvent were found to be good media for bitumen modification with formaldehyde [14]. But in the mentioned work there are no results regarding the effect of temperature, process time, amount and nature of the catalyst, as well as reagents ratio on the operational performance of the modified bitumen. So, the investigation of this effect is the aim of the present work.

\section{Experimental}

\subsection{Materials}

Tar for investigations was withdrawn at the JSC Ukrtatnaphta (Kremenchuk, Ukraine). Its characteristic is presented in Table 1.
Formaldehyde was used as $37 \%$ aqueous solution (formalin). The catalysts were: concentrated (37\%) hydrochloric acid with the density of $1.19 \mathrm{~g} / \mathrm{cm}^{3}$; concentrated sulfuric acid with the density of $1.83 \mathrm{~g} / \mathrm{cm}^{3}$; sodium hydroxide (white, opaque, hygroscopic crystals with the density of $2.13 \mathrm{~g} / \mathrm{cm}^{3}$ ); acid tar withdrawn at waste landfills (Lviv, Ukraine). Before using as a catalyst, acid tar was treated at $378 \mathrm{~K}$, then dried and mechanical impurities were removed. Tar moisture was $47.7 \%$, content of impurities was $3.6 \mathrm{wt} \%$. The characteristics of acid tar after treatment is given in Table 2.

To determine the adhesion we used crushed stone, the characteristics of which is given in [14].

\subsection{Experimental Procedure}

Modification of tar with formaldehyde was carried out according to the procedure described in [15]. The modification conditions are represented in Table 3.

Table 1

\section{Physico-chemical characteristics of tar}

\begin{tabular}{|l|c|c|}
\hline \multicolumn{1}{|c|}{ Index } & Value & Standard or Ref. \\
\hline Density at $293 \mathrm{~K}, \mathrm{~kg} / \mathrm{m}^{3}$ & 982.9 & {$[16]$} \\
\hline Initial boiling temperature, $\mathrm{K}$ & 659 & {$[16]$} \\
\hline Flash point (open cup), $\mathrm{E}$ & 555 & {$[16]$} \\
\hline Penetration at 298 K, 0.1mm & 247 & EN 1426:2015, IDT \\
\hline Softening point (R\&B), K & 312 & EN 1426:2015, IDT \\
\hline Ductility at 298 K, cm & 58.1 & {$[17]$} \\
\hline Adhesion to crushed stone, points & 2.5 & {$[18]$} \\
\hline Fraas breaking point, K & 255 & {$[19]$} \\
\hline Plastic range & 44 & {$[18]$} \\
\hline Penetration index & 0.16 & \\
\hline Ageing resistance at 436 K (RTFOT method) & & \\
- change in mass after RTFOT, wt \% & 0.35 & EN 12607-1:2015 \\
- softening point (R\&B) after RTFOT, K & 318.6 & \\
- penetration at 298 K after RTFOT, 0.1mm & 91 & \\
- $\Delta$ R\&B, K & 6.6 & \\
- residual penetration, \% & 36.8 & \\
\hline
\end{tabular}

Table 2

Characteristics of acid tar

\begin{tabular}{|l|c|}
\hline \multicolumn{1}{|c|}{ Index } & Value \\
\hline $\mathrm{pH}$ & 1.9 \\
\hline Density at $293 \mathrm{~K}, \mathrm{~kg} / \mathrm{m}^{3}$ & 982 \\
\hline Ash content, $\mathrm{wt} \%$ & 0.21 \\
\hline Moisture (analytical) content, $\mathrm{wt} \%$ & 0.78 \\
\hline Organic compounds content, $\mathrm{wt} \%$ & 94.5 \\
\hline Sulfur content, $\mathrm{wt} \%$ & 3.82 \\
\hline Freezing point, $\mathrm{K}$ & 309 \\
\hline $\begin{array}{l}\text { Viscosity according to viscosimeter } \\
\text { with d=5 mm at } 373 \mathrm{~K}, \mathrm{cSt}\end{array}$ & 99.1 \\
\hline Heat of combustion, $\mathrm{kJ} / \mathrm{kg}$ & 38668 \\
\hline
\end{tabular}


Conditions for tar modification with formaldehyde

\begin{tabular}{|l|c|}
\hline \multicolumn{1}{|c|}{ Index } & Value \\
\hline Tar amount, $\mathrm{wt} \%$ & 100 \\
\hline Formalin amount (including formaldehyde), wt \% & $10.0(3.7)$ \\
\hline Catalyst and its amount, $\mathrm{wt} \%$ & $\mathrm{HCl}, 2.5$ \\
& $\mathrm{H}_{2} \mathrm{SO}_{4}, 2.5$ \\
& $\mathrm{NaOH}, 1.0$ \\
& Acid tar, 5.0 \\
& Acid tar, 10.0 \\
\hline Temperature, $\mathrm{K}$ & 393 \\
\hline Time, $\mathrm{h}$ & 3.0 \\
\hline
\end{tabular}

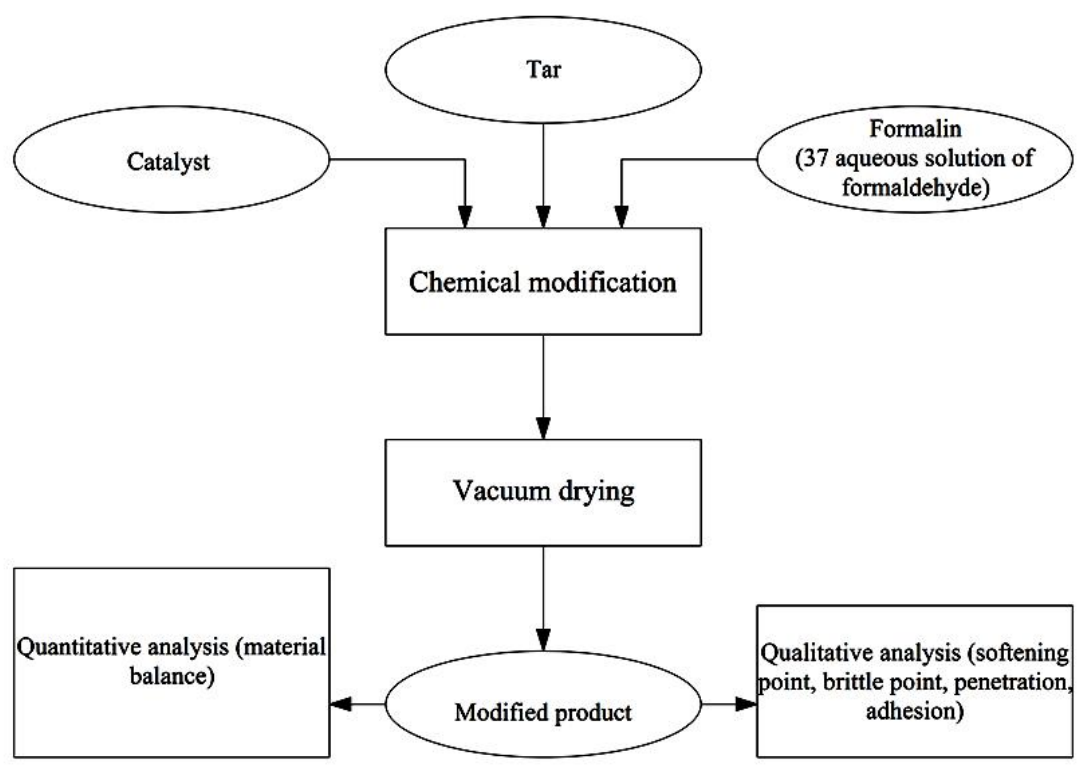

Fig. 1. Block diagram of tar modification with formaldehyde

The yield of modified tar $\left(X_{m o d}\right)$ was determined according to Eq. (1):

$$
\mathrm{X}_{\mathrm{mod}}=\frac{\mathrm{m}_{\mathrm{mod}}}{\mathrm{m}_{\mathrm{tar}}} \cdot 100 \%
$$

where $m_{\text {mod }}$ is the weight of the modified tar, $\mathrm{g} ; m_{t a r}$ is the weight of initial tar, g.

The block diagram of the process is given in Fig. 1.

The structural group composition of the modified tar was conducted according to the procedure described in [22].

\subsection{Methods of Analysis}

IR spectra were recorded using Thermo scientific Nicolet iS10 spectrophotometer. The results were identified using Thermo scientific Nicolet iS10 software.

The physico-technological characteristics of initial and modified tar were determined according to the standard methods, namely softening (R\&B) point (EN 1427:2015, IDT); penetration [EN 1426:2015, IDT]; adhesion to crushed stone [19] and Fraas breaking point [20].

\section{Results and Discussion}

It was shown earlier $[15,16]$ that modification of tar with low-molecular organic compounds is feasible to be carried out in the absence of organic solvents. Therefore, the effect of process main factors on the operational properties of bitumen obtained on the basis of modified tar was examined without solvents.

We examined the effect of amount and nature of the catalyst, process temperature and time, as well as tar:formaldehyde ratio on the softening point, penetration, Fraas breaking point and adhesion to crushed stone surface.

\subsection{Effect of Catalyst Nature and Amount}

It is known from the literature [23] that during production of arene-formaldehyde resins the acids and alkali are effective catalysts for arenes polycondensation with formaldehyde. That is why we used hydrochloric 
acid, sulfuric acid and sodium hydroxide in our investigations. We also used the wastes of refineries, so called acid tar. Acid tar was chosen due to strong acid $\mathrm{pH}$ value $(\mathrm{pH}=1.9$, Table 2$)$ provided by the presence of sulfuric acid and organic acids in the tar.

The experimental results are represented in Table 4.

Table 4

Effect of catalyst nature and amount on the characteristics of modified tar

\begin{tabular}{|c|c|c|c|c|c|}
\hline Sample & $\begin{array}{c}\text { Catalyst and its } \\
\text { amount per } 100 \mathrm{~g} \text { of } \\
\text { tar, } \mathrm{wt} \%\end{array}$ & $\begin{array}{c}\text { Softening point } \\
(\mathrm{R} \& \mathrm{~B}), \mathrm{K}\end{array}$ & $\begin{array}{c}\text { Penetration at } 298 \mathrm{~K}, \\
0.1 \mathrm{~mm}\end{array}$ & $\begin{array}{c}\text { Fraas breaking point, } \\
\mathrm{K}\end{array}$ & $\begin{array}{c}\text { Adhesion to crushed } \\
\text { stone, points }\end{array}$ \\
\hline FMT-1 & $\mathrm{HCl}, 2.5$ & 325 & 55 & 264 & 3.5 \\
\hline FMT-2 & $\mathrm{H}_{2} \mathrm{SO}_{4}, 2.5$ & 349 & 35 & 259 & 5.0 \\
\hline FMT-3 & $\mathrm{NaOH}, 1.0$ & 315 & 161 & 256 & 2.5 \\
\hline FMT-4 & Acid tar, 5.0 & 313 & 166 & 254 & 2.5 \\
\hline FMT-5 & Acid tar, 10.0 & 313 & 185 & 252 & 2.5 \\
\hline
\end{tabular}

Table 5

Effect of the catalyst amount on the properties of modified tar

\begin{tabular}{|c|c|c|c|}
\hline Sample & $\begin{array}{c}\text { Amount of } \mathrm{H}_{2} \mathrm{SO}_{4} \text { per } 100 \mathrm{~g} \\
\text { of tar, } \mathrm{wt} \%\end{array}$ & Fraas breaking point, $\mathrm{K}$ & $\begin{array}{c}\text { Adhesion to crushed stone, } \\
\text { points }\end{array}$ \\
\hline FMT-6 & 0 & 255.0 & 2.5 \\
\hline FMT-7 & 0.5 & 256.5 & 3.0 \\
\hline FMT-8 & 1.0 & 257.0 & 4.0 \\
\hline FMT-2 & 2.5 & 259.0 & 5.0 \\
\hline FMT-9 & 5.0 & 261.0 & 5.0 \\
\hline FMT-10 & 7.0 & 262.0 & - \\
\hline FMT-11 & 10.0 & 261.5 & - \\
\hline
\end{tabular}

Note: Samples FMT-6 and FMT-9 have homogeneous structure, FMT-10 and FMT-11 have inhomogeneous structure.

Taking into account the decrease in the values of softening point and the increase in penetration values, the catalysts efficiency may be represented as following:

$\mathrm{H}_{2} \mathrm{SO}_{4}<\mathrm{HCl}<\mathrm{NaOH}<$ acid tar

Sulfuric and hydrochloric acids were found to be the most effective catalysts for tar modification with formaldehyde. Moreover, sulfuric acid is considerably more active than hydrochloric acid.

If we compare the resulting values obtained in the presence of $\mathrm{H}_{2} \mathrm{SO}_{4}$ and $\mathrm{HCl}$, we see that the softening point is higher ( $349 \mathrm{~K} v$ s. $325 \mathrm{~K}$ ) and Fraas breaking point is lower $(259 \mathrm{~K} v s .264 \mathrm{~K})$. Moreover, the highest value of adhesion (5.0 points) was found when $\mathrm{H}_{2} \mathrm{SO}_{4}$ was used as the catalyst.

Therefore, further investigations were carried out using sulfuric acid as the catalyst. We studied the effect of catalyst amount on the properties of modified product. The amount of $\mathrm{H}_{2} \mathrm{SO}_{4}$ varied from 0.5 to $10 \mathrm{wt} \%$ per $100 \mathrm{~g}$ of initial tar, other experimental conditions were the same. The results obtained are represented in Table 5 and Fig. 2.

One can see from the results obtained that the amount of $\mathrm{H}_{2} \mathrm{SO}_{4}$ of more than $2.5 \mathrm{wt} \%$ virtually does not change the softening point and penetration. The increase in the catalyst amount above $5 \mathrm{wt} \%$ decreases the Fraas breaking point and with $7 \mathrm{wt} \%$ the samples became inhomogeneous. So, the catalyst amount of $2.5 \mathrm{wt} \%$ may be considered as the optimum one.

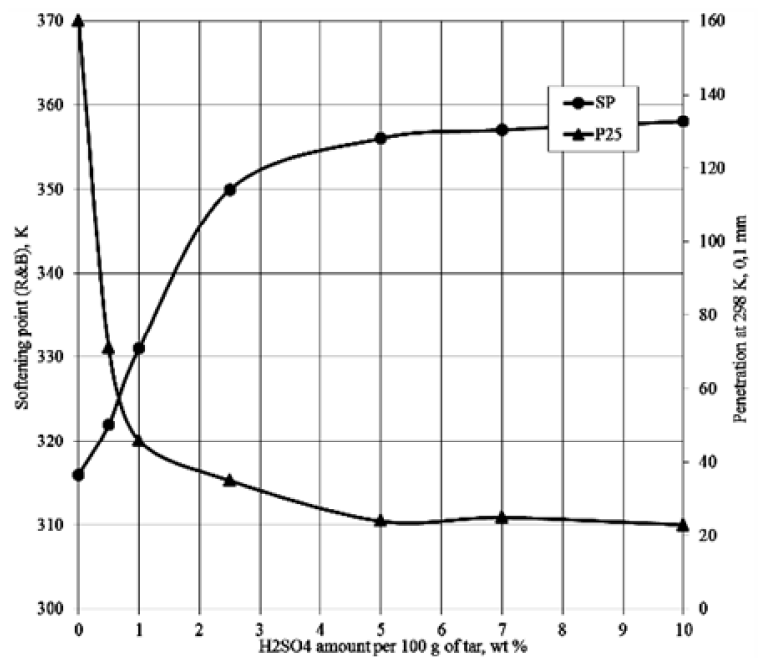

Fig. 2. Softening point and penetration $v s$. catalyst amount 
Effect of temperature on the properties of modified tar

\begin{tabular}{|c|c|c|c|}
\hline Sample & Temperature, K & Fraas breaking point, K & $\begin{array}{c}\text { Adhesion to crushed stone, } \\
\text { points }\end{array}$ \\
\hline FMT-12 & 313 & 256.0 & 3.0 \\
\hline FMT-13 & 333 & 256.5 & 3.5 \\
\hline FMT-14 & 353 & 259.5 & 5.0 \\
\hline FMT-15 & 373 & 259.0 & 5.0 \\
\hline FMT-2 & 393 & 259.0 & 5.0 \\
\hline FMT-16 & 413 & 257.5 & 5.0 \\
\hline FMT-17 & 433 & 258.0 & 5.0 \\
\hline
\end{tabular}

Note: All samples have homogeneous structure.

\subsection{Effect of Temperature}

It is known from the literature [23], that the polycondensation reaction of arenes and formaldehyde occurs at relatively low temperatures (313-333 K). Taking into account the viscosity of initial tar, the investigated range of temperatures was $313-433 \mathrm{~K}$, other process conditions were as given in Table 3. The experimental results are represented in Table 6 and Fig. 3.

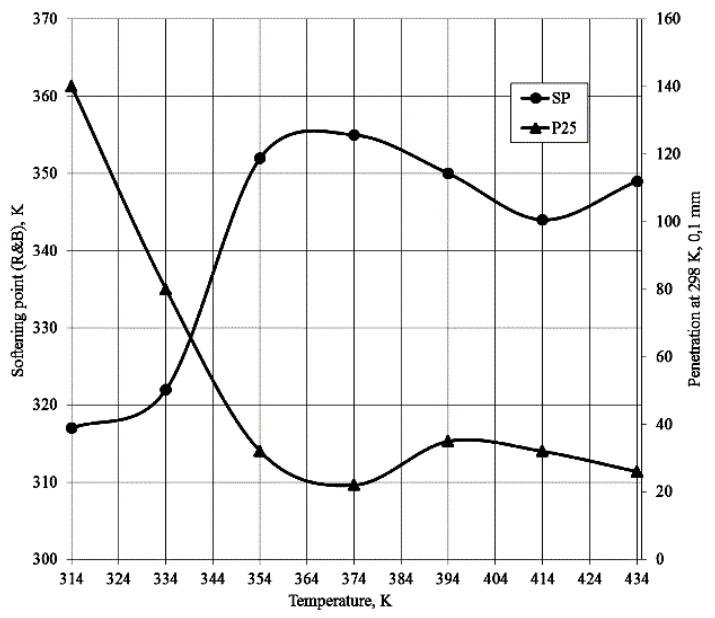

Fig. 3. Softening point and penetration vs. temperature

The increase in temperature to $373 \mathrm{~K}$ has an essential effect of the modification process. Further temperature increase insignificantly affects the examined values; and at $393 \mathrm{~K}$ even a slight decrease in softening point is observed. The adhesion achieves 5.0 points at $353 \mathrm{~K}$ and remains constant at higher temperatures. So, the temperature range of $353-393 \mathrm{~K}$ was taken as an optimum one.

\subsection{Effect of Process Time}

The effect of $0.5,1.0,2.0,3.0$ and $4.0 \mathrm{~h}$ process time was studied; process temperature was $373 \mathrm{~K}$; catalyst $\mathrm{H}_{2} \mathrm{SO}_{4} \quad(2.5 \mathrm{wt} \%)$. The experimental results are represented in Table 7 and Fig. 4.

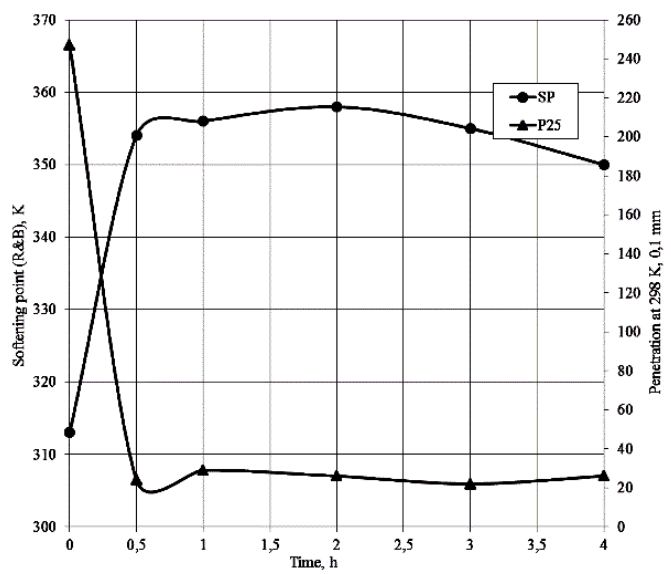

Fig. 4. Softening point and penetration $v s$. time

Effect of process time on the properties of modified tar

\begin{tabular}{|c|c|c|c|}
\hline Sample & Time, $\mathrm{h}$ & Fraas breaking point, $\mathrm{A}$ & $\begin{array}{c}\text { Adhesion to crushed stone, } \\
\text { points }\end{array}$ \\
\hline FMT-18 & 0.5 & 258.0 & 5.0 \\
\hline FMT-19 & 1.0 & 259.0 & 5.5 \\
\hline FMT-20 & 2.0 & 259.5 & 5.0 \\
\hline FMT-15 & 3.0 & 259.0 & 5.0 \\
\hline FMT-21 & 4.0 & 259.5 & 5.0 \\
\hline
\end{tabular}

Note: The sample FMT-21 has an inhomogeneous structure. 
It is obvious that the main changes are observed for $0.5 \mathrm{~h}$. Further increase in time does not lead to essential changes in softening point and penetration (Fig. 4).

In accordance with the procedure of modification (see subsection 2.2), the process is carried out in a sealed vessels under increased pressure due to the ability of formaldehyde to be evaporated at the process temperature $(373 \mathrm{~K})$. After the process finishing (for example, after $0.5 \mathrm{~h}$ ), the vessel is opened, the product is transferred into a vacuum drying cabinet and dried at $393 \mathrm{~K}$ for $3 \mathrm{~h}$. So, we assume that the structure of formaldehyde modified tar is formed in the sealed vessel (for $0.5 \mathrm{~h}$ ), as well as during drying in the cabinet (at $393 \mathrm{~K}$ for $3 \mathrm{~h}$ ).

\subsection{Effect of Reagents Ratio}

The effect of tar:formaldehyde ratio was examined at the process temperature of $373 \mathrm{~K}$, time $0.5 \mathrm{~h}$, $\mathrm{H}_{2} \mathrm{SO}_{4}$ as the catalyst $(2.5 \mathrm{wt} \%)$. The ratio varied from 1.0 to $20 \mathrm{wt} \%$. The process without formaldehyde was studied for the comparison. The results obtained are represented in Table 8 and Fig. 5.

The increase in formalin amount from 2.5 to $5.0 \mathrm{wt} \%$ increases the softening point to $355 \mathrm{~K}$ and decreases penetration to $26.0 .1 \mathrm{~mm}$. Further increase in formalin amount to $3.7 \mathrm{wt} \%$ and $7.4 \mathrm{wt} \%$ does not virtually change the mentioned values. The maximum of

Table 8

Effect of reagents ratio on the properties of modified tar

\begin{tabular}{|c|c|c|c|}
\hline Sample & $\begin{array}{c}\text { Formalin amount (including } \\
\text { formaldehyde), wt } \% \text { relative to tar }\end{array}$ & Fraas breaking point, $\mathrm{K}$ & $\begin{array}{c}\text { Adhesion to crushed stone, } \\
\text { points }\end{array}$ \\
\hline FMT-22 & 0 & 255.0 & 2.5 \\
\hline FMT-23 & $1.0(0.37)$ & 257.0 & 3.5 \\
\hline FMT-24 & $2.5(0.925)$ & 262.0 & 4.5 \\
\hline FMT-25 & $5.0(1.85)$ & 263.0 & 5.0 \\
\hline FMT-18 & $10.0(3.70)$ & 258.0 & 5.0 \\
\hline FMT-26 & $15.0(5.55)$ & 261.0 & 5.0 \\
\hline FMT-27 & $20.0(7.40)$ & 261.5 & 5.0 \\
\hline
\end{tabular}

Note: The sample FMT-27 has an inhomogeneous structure.

Table 9

Effect of mixture components on the characteristics of modified tar

\begin{tabular}{|c|c|c|c|c|c|}
\hline \multirow[b]{2}{*}{ Sample } & \multirow{2}{*}{$\begin{array}{c}\text { Amount of } \\
\text { formylating agent, } \\
\mathrm{wt} \% \text { relative to } \\
\text { initial tar }\end{array}$} & \multicolumn{2}{|c|}{ Amount in formylating agent, wt $\%$} & \multirow[b]{2}{*}{$\begin{array}{c}\text { Fraas breaking } \\
\text { point, } \mathrm{K}\end{array}$} & \multirow[b]{2}{*}{$\begin{array}{c}\text { Adhesion to } \\
\text { crushed stone, } \\
\text { points }\end{array}$} \\
\hline & & $\begin{array}{l}\text { Formalin } \\
\text { (including } \\
\text { formaldehyde) }\end{array}$ & Catalyst $\left(\mathrm{H}_{2} \mathrm{SO}_{4}\right)$ & & \\
\hline \multicolumn{6}{|c|}{ Formalin : catalyst $(\mathrm{w} / \mathrm{w})=1.0$} \\
\hline FMT-28 & 2.0 & $1.0(0.37)$ & 1.0 & 256.0 & 3.0 \\
\hline FMT-24 & 5.0 & $2.5(0.925)$ & 2.5 & 262.0 & 4.5 \\
\hline FMT-29 & 10.0 & $5.0(1.85)$ & 5.0 & 266.5 & 5.0 \\
\hline FMT-30 & 20.0 & $10.0(3.7)$ & 10.0 & 272.5 & 5.0 \\
\hline \multicolumn{6}{|c|}{ Formalin : catalyst $(\mathrm{w} / \mathrm{w})=2.0$} \\
\hline FMT-31 & 1.5 & $1.0(0.37)$ & 0.5 & 256.0 & 2.5 \\
\hline FMT-32 & 3.75 & $2.5(0.925)$ & 1.25 & 259.5 & 4.0 \\
\hline FMT-25 & 7.5 & $5.0(1.85)$ & 2.5 & 263.0 & 5.0 \\
\hline FMT-33 & 15.0 & $10.0(3.7)$ & 5.0 & 265.0 & 5.0 \\
\hline FMT-34 & 22.5 & $15.0(5.55)$ & 7.5 & 270.5 & 5.0 \\
\hline \multicolumn{6}{|c|}{ Formalin : catalyst $(\mathrm{w} / \mathrm{w})=4.0$} \\
\hline FMT-35 & 1.25 & $1.0(0.37)$ & 0.25 & 255.5 & 2.5 \\
\hline FMT-36 & 3.125 & $2.5(0.925)$ & 0.625 & 265.0 & 3.0 \\
\hline FMT-37 & 6.25 & $5.0(1.85)$ & 1.25 & 262.5 & 3.0 \\
\hline FMT-18 & 12.5 & $10.0(3.7)$ & 2.5 & 258.0 & 5.0 \\
\hline FMT-38 & 18.75 & $15.0(5.55)$ & 3.75 & 266.0 & 5.0 \\
\hline
\end{tabular}

Note: The samples FMT-30 and FMT-34 have an inhomogeneous structure. 
adhesion value (4.5-5.0 points) is achieved at formalin amount of $2.5-5.0 \mathrm{wt} \%$ relative to tar (formaldehyde amount $0.925-1.85 \mathrm{wt} \%$ ) and just this amount was chosen as an optimum one. The process proceeding without formaldehyde (sample FMT-22) shows the softening point of $313 \mathrm{~K}$ and penetration of $195 \cdot 0.1 \mathrm{~mm}$.

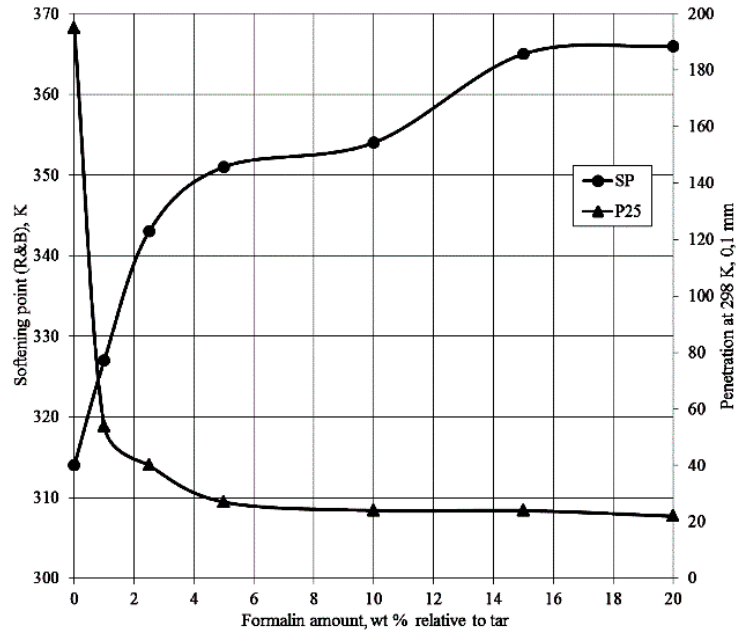

Fig. 5. Softening point and penetration vs. reagents ratio

The operational characteristics of modified tar are influenced not only by the formaldehyde amount in the mixture but the ratio of formalin : sulfuric acid as well. Therefore we studied the ratio of formylating agent (formalin : catalyst) equal to 1,2 and 4 at the formalin amount of $1.0-15.0 \mathrm{wt} \%$ per $100 \mathrm{~g}$ of initial tar. The process temperature was $373 \mathrm{~K}$, process time was $0.5 \mathrm{~h}$.

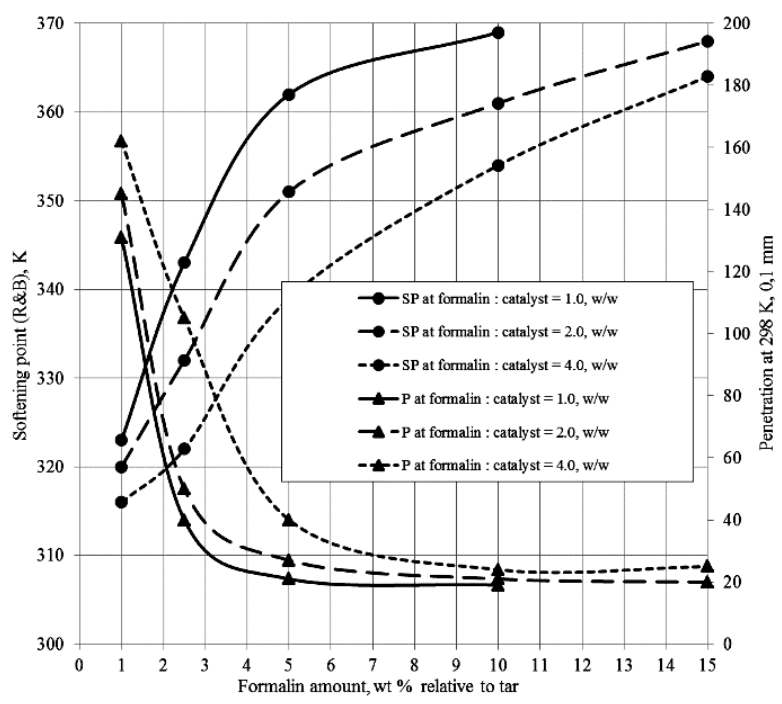

Fig. 6. Effect of formalin amount at different ratios of formalin : catalyst
The experimental results are represented in Table 9 and Figs. 6, 7.

At the same amount of formalin with the increase in formalin : catalyst ratio from 1.0 to 4.0 the value of softening point decreases and the penetration value increases. This allows to assert that the best results are achieved at formalin : catalyst ratio equal to $1.0, \mathrm{w} / \mathrm{w}$.

At the same formalin: catalyst ratio with the increase in formalin amount from 1.0 to 10.0 the value of softening point increases and the penetration value decreases. This allows to assert that the optimum amount of formalin is $5.0 \mathrm{wt} \%$ relative to initial tar at formalin : catalyst ratio equal to $1.0, \mathrm{w} / \mathrm{w}$.

\subsection{Chemistry of the Tar Modification Process with Formaldehyde}

Tar, which is used today for the production of bitumen, is characterized by the complex structure [24]. Modern instrumental methods allow to distinguish in tar structure the groups of hydrocarbons, which are characterized by definite properties. These groups are: carbenes and carboids, oils, resins and asphaltenes. Among the mentioned groups only oils and resins contain enough aromatic hydrocarbons capable to react with formaldehyde.

To establish the process chemistry, the known reactions of formaldehyde with the compounds containing aromatic rings were used $[25,26]$. The group composition of the modified tar was determined, as well as the composition of the products obtained due to the reaction of formaldehyde with "pure" aromatic compounds.

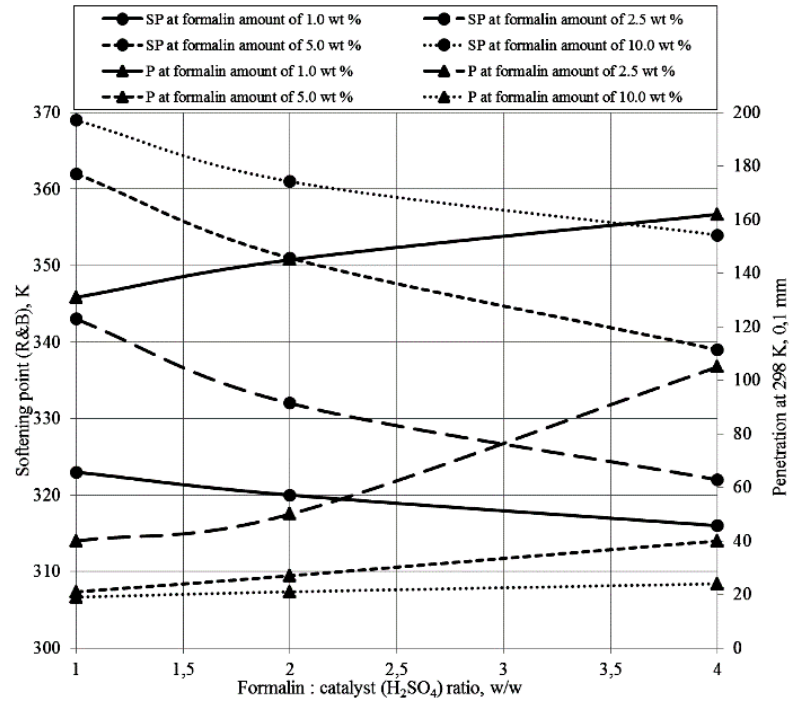

Fig. 7. Effect of formalin : catalyst $\left(\mathrm{H}_{2} \mathrm{SO}_{4}\right)$ ratio at different amounts of formalin 
It is known [25] that formaldehyde in aqueous solutions is in a hydrated form:<smiles>O=COCCO</smiles>

If formaldehyde reacts with aromatic hydrocarbons in the presence of strong acid catalysts (hydrochloric or sulfuric acid), the positively charged ion ${ }^{+} \mathrm{CH}_{2} \mathrm{OH}$ is formed:<smiles>O=[C+]OC(O)O</smiles>

The formation of ${ }^{+} \mathrm{CH}_{2} \mathrm{OH}$ ion may occur also due to the reaction of formaldehyde with hydrogen cation:<smiles></smiles>

Thus, we assume that the positively charged ion ${ }^{+} \mathrm{CH}_{2} \mathrm{OH}$, which is formed due to Eqs. (3-4), attacks the hydrogen of aromatic ring, which is in the structure of tar, according to Eqs. (5-7).
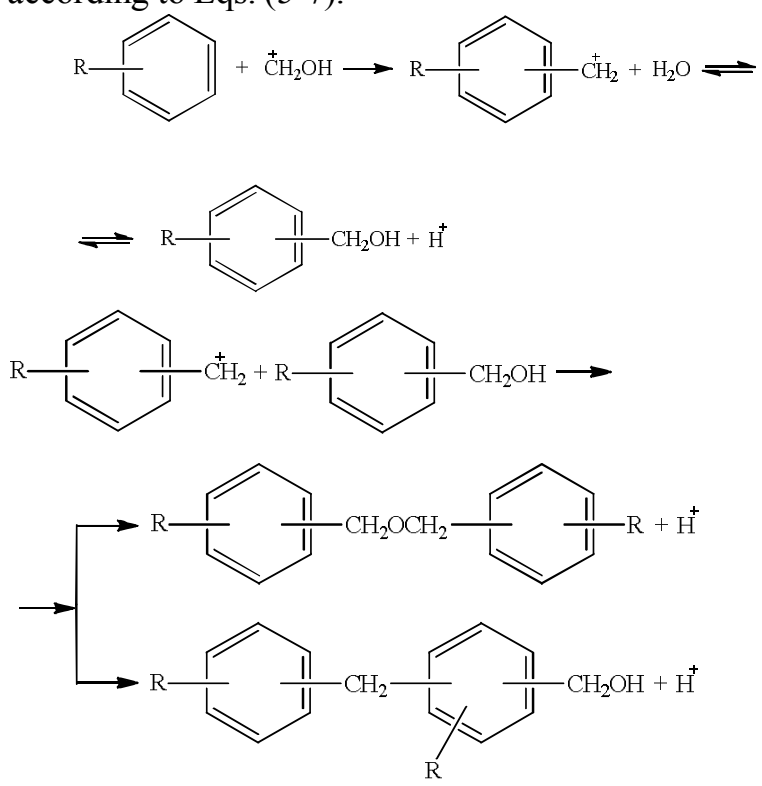

The product, which is formed according to Eq. (6), may be transformed according to Eq. (8) in the presence of $\mathrm{H}^{+}$:

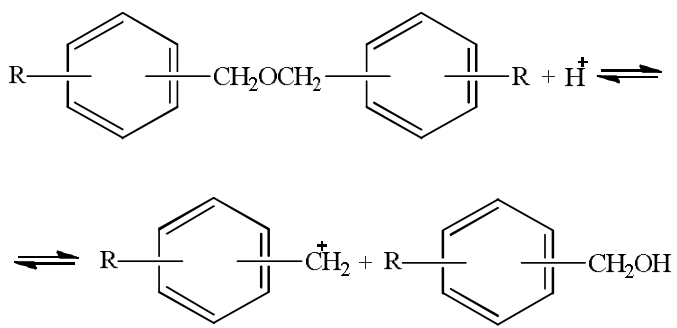

Then the formed ion may react as following:

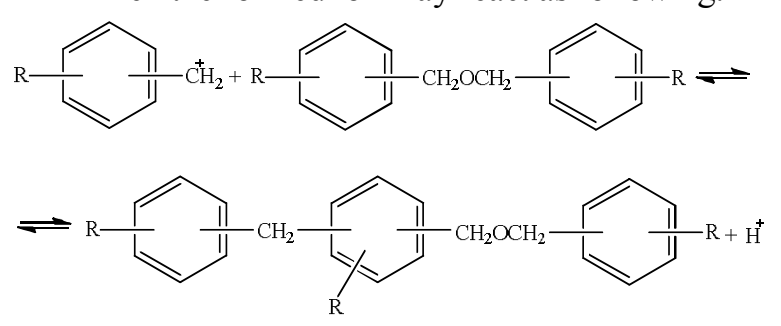

The general equation of the process may be given as:
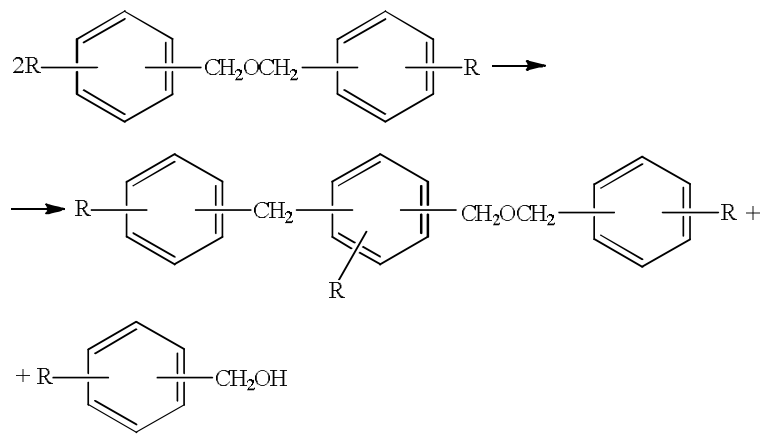

To establish the chemical transformations occurred during tar modification with formaldehyde, the products were obtained according to the procedure described in subsection 2.2 and their group composition was determined. The conditions for tar modification were chosen based on the described above results and its characteristics is given in Table 10. The results of group analysis are represented in Table 11.

Table 10

\section{Conditions and characteristics of modified tar}

\begin{tabular}{|c|c|c|c|c|c|c|}
\hline \multirow{2}{*}{ Sample } & \multicolumn{2}{|c|}{ Modification conditions } & \multicolumn{4}{|c|}{ Product characteristics } \\
\cline { 2 - 7 } & $\begin{array}{c}\text { Amount of } \\
\text { formalin, } \\
\mathrm{wt} \% \text { relative to tar }\end{array}$ & $\begin{array}{c}\mathrm{H}_{2} \mathrm{SO}_{4} \text { amount, } \\
\mathrm{wt} \% \text { relative to tar }\end{array}$ & $\begin{array}{c}\text { Softening point } \\
\text { (R\&B), K }\end{array}$ & $\begin{array}{c}\text { Ductility at } \\
298 \mathrm{~K}, \mathrm{~cm}\end{array}$ & $\begin{array}{c}\text { Penetration at } \\
298 \mathrm{~K}, 0.1 \mathrm{~mm}\end{array}$ & $\begin{array}{c}\text { Fraas breaking } \\
\text { point, K }\end{array}$ \\
\hline FMT-39 & 1.0 & 1.1 & 321.0 & 42 & 144 & 256 \\
\hline FMT-40 & 1.9 & 1.7 & 332.0 & 4 & 48 & 258 \\
\hline FMT-41 & 3.0 & 3.2 & 356.5 & 4 & 264 \\
\hline
\end{tabular}

Notes: process temperature is $378-383 \mathrm{~K}$, process time is $0.6-0.8 \mathrm{~h}$. 
Group analysis of tars

\begin{tabular}{|c|c|c|c|c|c|c|c|}
\hline & & \multicolumn{4}{|c|}{ Content of components in tar } & \multirow[b]{2}{*}{ Losses } & \multirow[b]{2}{*}{ Total content } \\
\hline \multicolumn{2}{|c|}{ Tar } & Carbenes and & Oils & Resins & A snbaltenes & & \\
\hline \multirow{2}{*}{ Initial tar } & weight, $g$ & 0.01 & 2.48 & 1.45 & 0.79 & 0.25 & 4.98 \\
\hline & $w t \%$ & 0.20 & 49.80 & 29.12 & 15.86 & 5.02 & 100.00 \\
\hline \multirow{2}{*}{ FMT-39 } & weight, $g$ & 0.01 & 2.18 & 1.30 & 1.02 & 0.25 & 4.76 \\
\hline & $\mathrm{wt} \%$ & 0.21 & 45.80 & 27.31 & 21.43 & 5.25 & 100.00 \\
\hline \multirow{2}{*}{ FMT-40 } & weight, $\mathrm{g}$ & 0.01 & 2.70 & 0.93 & 1.12 & 0.25 & 5.01 \\
\hline & $\mathrm{wt} \%$ & 0.19 & 53.90 & 18.56 & 22.35 & 5.00 & 100.00 \\
\hline \multirow{2}{*}{ FMT-41 } & weight, $\mathrm{g}$ & 0.01 & 2.53 & 1.03 & 1.22 & 0.22 & 5.01 \\
\hline & $\mathrm{wt} \%$ & 0.20 & 50.49 & 20.56 & 24.35 & 4.40 & 100.00 \\
\hline
\end{tabular}

It is seen from Table 11 that both initial and modified tars contain small amount of carbenes and carboids but the quantity of oils, resins and asphaltenes is large. Moreover, this amount depends on the amount of introduced formaldehyde and catalyst as well (Table 10). The introduction of $1 \mathrm{wt} \%$ of formaldehyde and $1.1 \mathrm{wt} \%$ of $\mathrm{H}_{2} \mathrm{SO}_{4}$ (sample FMT-39) leads to the decrease in oils amount to compare with the initial tar. However, further increase in the amounts of formaldehyde and catalyst results in the increase of the mentioned value. This indicates that during modification, apart from Eqs. (5-10), the reaction of acid and paraform (paraformaldehyde) occurs. Paraform is formed according to Eq. (11) [27] due to the storage of formaldehyde aqueous solution at room temperature.

$$
(\mathrm{n}+1) \mathrm{CH}_{2} \mathrm{O}+\mathrm{H}_{2} \mathrm{O} \longrightarrow \mathrm{HOCH}_{2} f \mathrm{OCH}_{2}+\mathrm{nOH}
$$

Paraform is a mixture of compounds with different molecular weights and structures. In the presence of $\mathrm{H}_{2} \mathrm{SO}_{4}$ paraform is stable but in the presence of alkaline it is capable of depolymerization with formaldehyde evolving.

On the other hand, in the presence of sulfuric acid under the modification conditions paraform reacts with the acid according to Eq. (12) [27]:

$$
\mathrm{HOCH}_{2} \mathrm{fOCH}_{2}+\mathrm{nOH}+2 \mathrm{H}_{2} \mathrm{SO}_{4} \rightarrow\left\|_{0}\right\|_{0} \prod_{0}
$$

So, the increase in $\mathrm{H}_{2} \mathrm{SO}_{4}$ amount (samples FMT-40 and FMT-41) results in the proceeding of Eqs. (5-10) and Eq. (12). The latter one provides the increase in oils amount in modified tar, which is in agreement with the results represented in Table 11 .

The analysis of resins content in tars indicates that the increase in amount of both formaldehyde and catalyst decreases the resins amount with the increase in asphaltenes amount. This means that resins are converted into asphaltenes. Such conversion increases the aromaticity of the system and the content of methylene carbon. The latter is provided by the proceeding of Eqs. (5-10), i.e., formaldehyde molecules attachment to aromatic rings of the tar.

All mentioned above indicate only the possibility of reactions proceeding due to the high complexity of tar structure and therefore it cannot be studied more detailed. The only thing that is reliable is that oils and resins in the tar composition contain mono-, bi- and polycyclic hydrocarbons, including those with aromatic structure.

To confirm the proceeding of modification reactions (5-10) we examined the reaction of formaldehyde with "pure" aromatic compounds, namely toluene and $p$-xylene.

The conditions for aromatic compounds modification with formaldehyde are represented in Table 12.

Table 12

Reaction conditions for aromatic compounds and formaldehyde

\begin{tabular}{|c|c|}
\hline Index & Value \\
\hline Aromatic compound, $\mathrm{g}$ & 100.0 \\
\hline Reaction temperature, $\mathrm{K}$ & 393 \\
\hline Reaction time, $\mathrm{h}$ & 3 \\
\hline Amount of formaldehyde per 100 $\mathrm{g}$ of aromatic compound, $\mathrm{g}$ & 10.0 \\
\hline Amount of catalyst $(\mathrm{HCl}$ ) per 100 $\mathrm{g}$ of aromatic compound, $\mathrm{g}$ & 2.5 \\
\hline Yield of resin based on toluene, $\mathrm{g}$ & 80.0 \\
\hline Yield of resin based on $p$-xylene, $\mathrm{g}$ & 92.2 \\
\hline
\end{tabular}




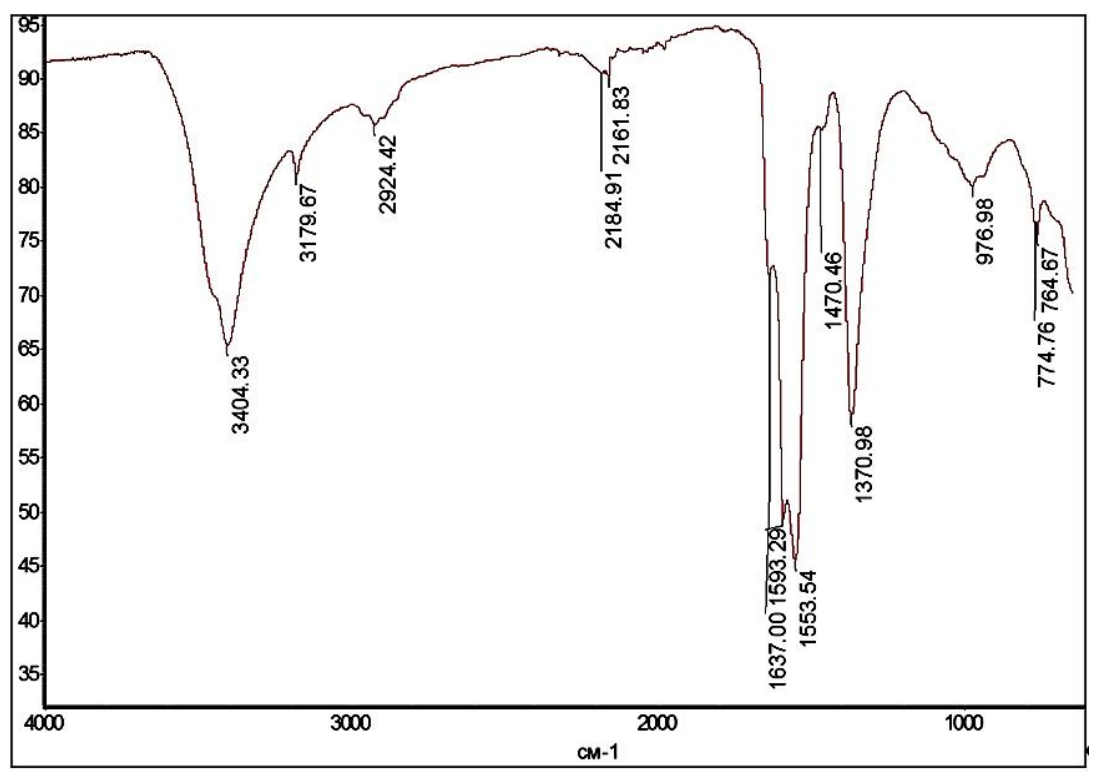

Fig. 8. IR spectrum of the toluene based resin

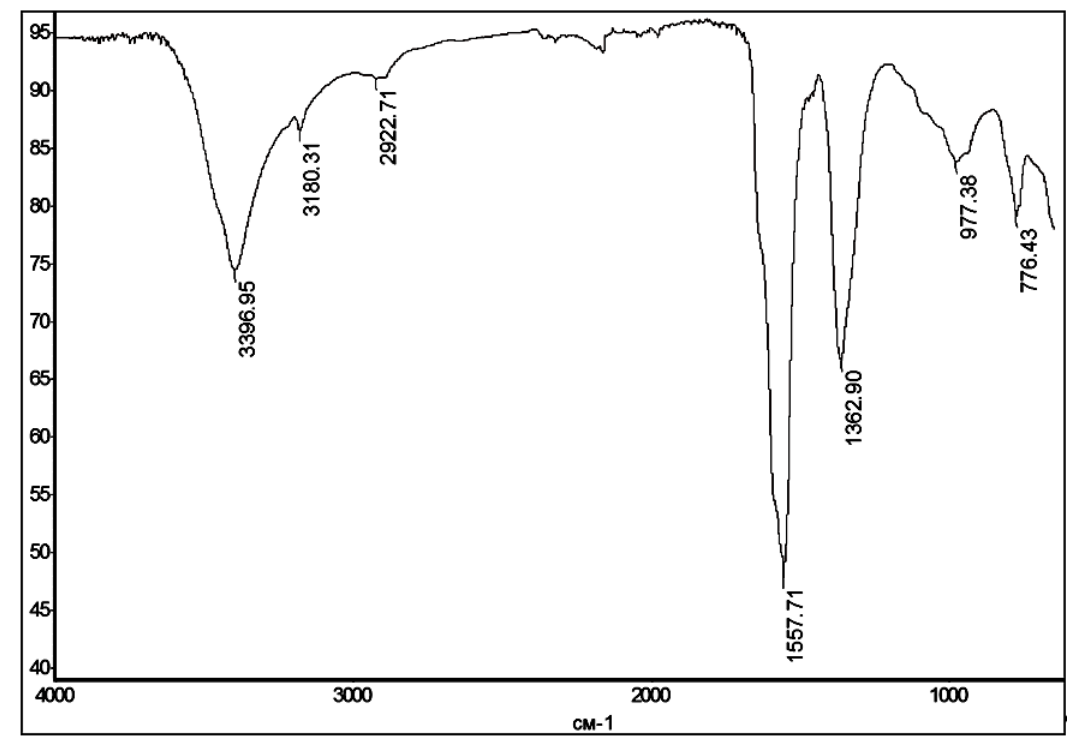

Fig. 9. IR spectrum of the $p$-xylene based resin

To synthesize arene-formaldehyde resins based on toluene and $p$-xylene, a hydrochloric acid was used. This is to avoid the interaction of acid and paraform according to Eq. (12).

To establish the structure of the synthesized areneformaldehyde reins the IR spectroscopy was used [28]. The recorded spectra of resins based on toluene and $p$ xylene are given in Figs. 8 and 9, respectively.

Fig. 8 shows the absorption band at $3404 \mathrm{~cm}^{-1}$, indicating the presence of free hydroxy groups in the compound. This confirms the proceeding of the reactions (5-8) and (10). The presence of methylene group $\left(\mathrm{CH}_{3}-\right)$ in toluene is confirmed by the stretching vibrations at $3180 \mathrm{~cm}^{-1}$, the presence of benzene rings - by the bands at 1637, 1593 and $1554 \mathrm{~cm}^{-1}$. Mono- and disubstituted aromatic ring are proved by vibrations at 775 and $977 \mathrm{~cm}^{-1}$, respectively. The results show the introduction of aromatic rings in the structure of resin. $\mathrm{CH}_{2}-$ bonds formed according to the reactions (5-10) are confirmed by the stretching vibrations at $2924 \mathrm{~cm}^{-1}$. The $-\mathrm{CH}_{2} \mathrm{O}$ - group is confirmed by the band at $1371 \mathrm{~cm}^{-1}$.

Similar results were obtained when analyzing the IR spectrum of the resin based on $p$-xylene and formaldehyde (Fig. 9). The presence of hydroxy groups is 
confirmed by the stretching vibrations at $3397 \mathrm{~cm}^{-1}$, benzene rings - at $1558 \mathrm{~cm}^{-1},-\mathrm{CH}_{2} \mathrm{O}$ - group - at $1363 \mathrm{~cm}^{-1},-\mathrm{CH}_{2}-$ bond - at $2963 \mathrm{~cm}^{-1}$ and free $\mathrm{CH}_{3}-$ groups in xylene - at $3180 \mathrm{~cm}^{-1}$. The attachment of molecules to xylene is proved by the bands at 776 and $977 \mathrm{~cm}^{-1}$.

So, despite the complexity of tar structure the results obtained confirm tar modification with formaldehyde in accordance with Eqs. (5-10).

\subsection{IR Spectroscopic Characteristics of Modified Tar}

To confirm the structure of the modified tar we recorded IR spectra of samples FMT-40 and FMT-41, the characteristics of which is represented in Table 10. The spectrum of initial tar was taken for the comparison.

The presence of benzene rings in initial tar (Fig. 10) is confirmed by the absorption band at $1457 \mathrm{~cm}^{-1}$ corresponding to the stretching vibrations of the ring. Moreover, benzene rings are disubstituted (bands at 812 and $744 \mathrm{~cm}^{-}$ $\left.{ }^{1}\right)$ and trisubstituted $\left(720 \mathrm{~cm}^{-1}\right)$. The molecule fragments are connected to each other by methylene bonds, what is confirmed by the absorption bands at 2919 and $2850 \mathrm{~cm}^{-1}$, corresponding to asymmetric vibrations of $\mathrm{CH}_{2}-$ group in $\mathrm{RCH}_{2} \mathrm{R}^{\prime}$. Free methyl groups in the molecules of tar are proved by the symmetric deformational vibrations at $1375 \mathrm{~cm}^{-1}$ typical of $\mathrm{RCH}\left(\mathrm{CH}_{3}\right)_{2}$ fragment.

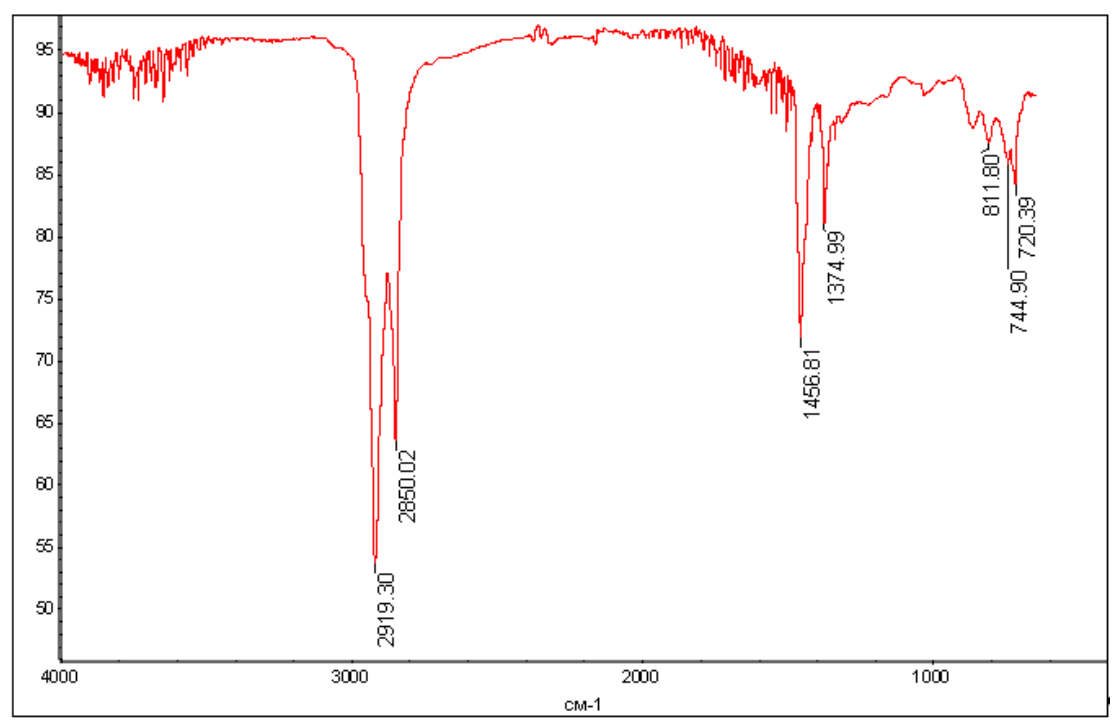

Fig. 10. IR spectrum of initial tar

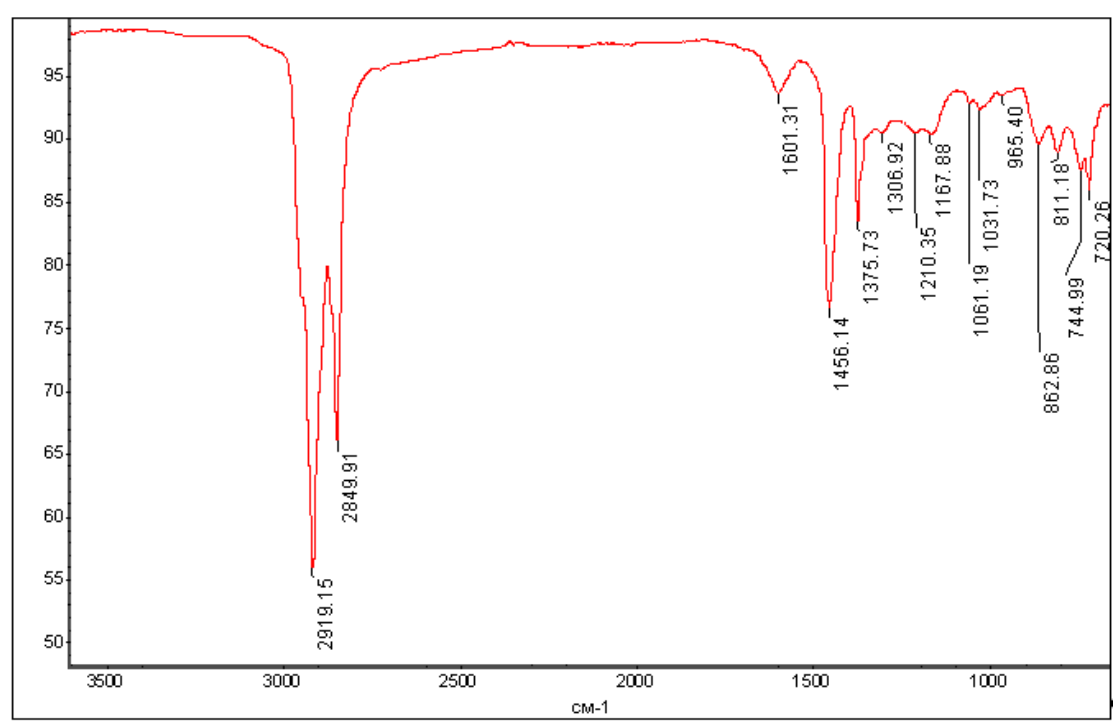

Fig. 11. IR spectrum of FMT-40 


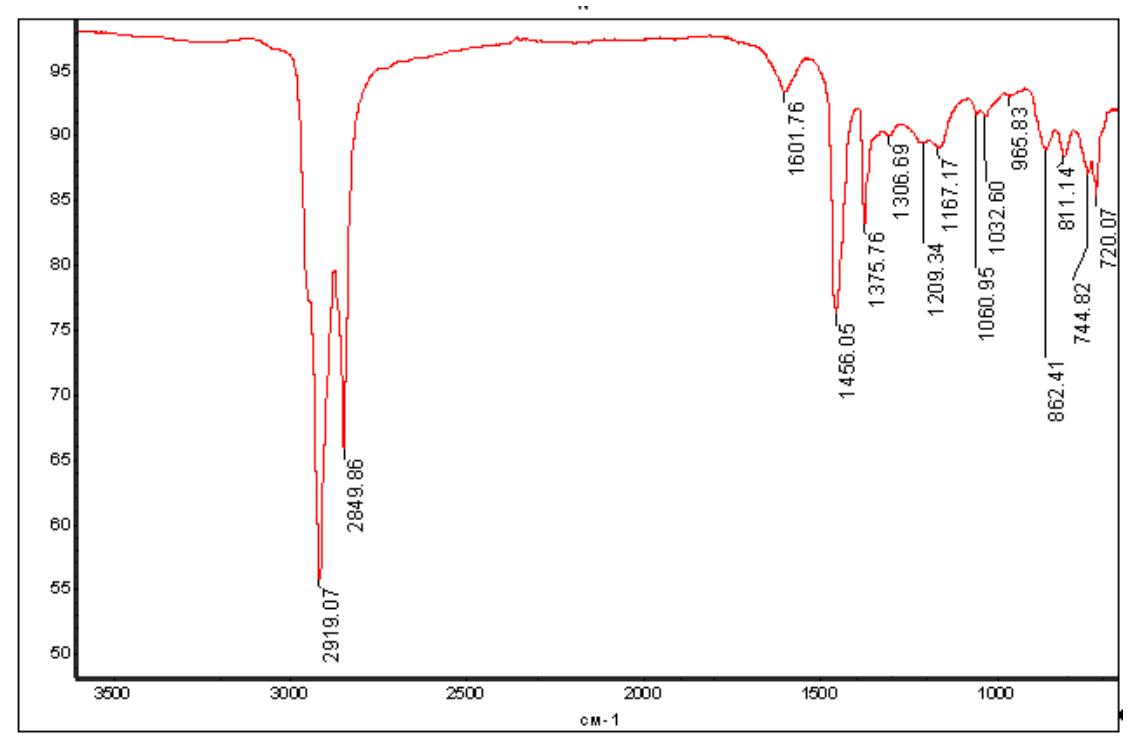

Fig. 12. IR spectrum of FMT-41

In the spectrum of FMT-40 (Fig. 11) the absorption bands at 2919 and $2850 \mathrm{~cm}^{-1}$ are observed, which confirm the presence of $\mathrm{CH}_{2}-$ groups in the modified product. The presence of benzene rings is confirmed by the bands at 1601 and $1456 \mathrm{~cm}^{-1}$, and their substitution is proved by the absorption bands at 863,811 and $745 \mathrm{~cm}^{-1}$. When comparing the spectra of initial and modified tars, in the spectrum of FMT-40 we observe the appearance of the bands at 1375 and $1061 \mathrm{~cm}^{-1}$ corresponding to the stretching vibrations of $-\mathrm{CH}_{2} \mathrm{O}-$ group and esteric bond $-\mathrm{C}-\mathrm{O}-\mathrm{C}-$, respectively [28]. This fact confirms the introduction of formaldehyde molecule into the structure of tar. The bands at 1210, 1167 and $1032 \mathrm{~cm}^{-1}$ [28] indicate the presence of sulfuric acid fragments $\left(\mathrm{RSO}_{3} \mathrm{H}\right)$ in tar structure. This indicates that sulfuric acid not only plays a role of catalyst but reacts with the mixture components (Eq. 12).

Similar results were obtained when recording IR spectrum of FMT-41 (Fig. 12), where we observe benzene rings $\left(1602,1456,862,811\right.$ and $\left.745 \mathrm{~cm}^{-1}\right), \mathrm{CH}_{2}-$ group (2919 and $2850 \mathrm{~cm}^{-1}$ ) and fragments related to the introduction of formaldehyde molecules into the structure of tar. The same as FMT-40, the modified product contains sulfo-groups $\left(1209,1167\right.$ and $\left.1033 \mathrm{~cm}^{-1}\right)$, which confirm the participation of sulfuric acid in chemical transformations of tar.

\section{Conclusions}

The process of chemical modification of tar (produced by JSC Ukrtatnafta, Kremenchuk, Ukraine) with formaldehyde as $37 \%$ aqueous solution was investigated in the presence of various catalysts.
Hydrochloric acid, sulfuric acid, powdered sodium hydroxide and acid tar were used as the catalysts. The concentrated sulfuric acid was found to be the most effective catalyst. Acid tar is inefficient for this process. The $\mathrm{H}_{2} \mathrm{SO}_{4}$ amount of $2.5 \mathrm{wt} \%$ relative to initial tar was found to be the optimum; softening point at this concentration was $349 \mathrm{~K}$. The maximum adhesion to the crushed stone (5 points) was achieved already at $353 \mathrm{~K}$ and taking into account the tar's viscosity, the process temperature was $353-393 \mathrm{~K}$. Process time was 1.0 hour. The optimum amount of formalin was up to $5 \mathrm{wt} \%$, which corresponds to formaldehyde content of $0.925-1.85 \mathrm{wt} \%$, at formalin : sulfuric acid ratio equal to 1 .

The structure of the modified products was proved by IR spectroscopy, which confirmed the introduction of formaldehyde molecules into the structure of modified tar. Chemistry of the process was proposed using the results of group analysis and reactions of toluene and $p$-xylene with formaldehyde.

\section{Acknowledgements}

This work was supported by the National Research Foundation of Ukraine (Grant No. 2020.02/0038).

\section{References}

[1] McNally T. (Ed): Polymer Modified Bitumen. Properties and Characterization. Woodhead Publ., 2011. https://doi.org/10.1533/9780857093721

[2] Pyshyev S., Gunka V., Grytsenko Yu. et al.: Chem. Chem. Technol., 2016, 10, 631. https://doi.org/10.23939/chcht10.04si.631 [3] Grynyshyn O., Bratychak M., Krynytskiy V. et al.: Chem. Chem. Technol., 2008, 2, 47.

https://doi.org/10.23939/chcht02.01.047 
[4] Bratychak M., Chervinskyy T., Astakhova O. et al.: Chem. Chem. Technol., 2010, 4, 325.

https://doi.org/10.23939/chcht04.04.325

[5] Bratychak M., Grynyshyn O., Astakhova O. et al.: Ecol. Chem. Eng. S, 2010, 17, 309.

[6] Bratychak M., Grynyshyn O., Prysiazhnyi Yu., Pushak A.: Naftopolimerni Smoly iz Funktsiinymy Grupamy. Syntez,

Vlastyvosti, Zastosuvannia. Monografia. Vyd-vo Lviv Polytechnic, Lviv 2016.

[7] Ivashkiv O., Astakhova O., Shyshchak O. et al.: Chem. Chem. Technol., 2015, 9, 69. https://doi.org/10.23939/chcht09.01.069

[8] Bratychak M., Iatsyshyn O., Shyshchak O. et al.: Chem. Chem. Technol., 2017, 11, 49. https://doi.org/10.23939/chcht11.01.049

[9] Bratychak M., Shyshchak O., Astakhova O., Ivashkiv O.: Oligomers with Functional Groups Based on Epoxy Resins. Synthesis, Properties and Application. Lviv Polytechnic Publ. House, Lviv 2019.

[10] Strap G., Astakhova O., Lazorko O. et al.: Chem. Chem. Technol., 2013, 7, 279. https://doi.org/10.23939/chcht07.03.279

[11] Astakhova O., Shved M., Zubal O. et al.: Chem. Chem. Technol., 2019, 13, 112. https://doi.org/10.23939/chcht13.01.112 [12] Sidun Yu., Solodkyy S., Shved M. et al.: Chem. Chem. Technol., 2019, 13, 489. https://doi.org/10.23939/chcht13.04.489 [13] Bratychak M., Shyshchak O., Astakhova O., Gunka V.: Oligomers Based on Cyclic Compounds. Synthesis, Properties and Application. Lviv Polytechnic Publ. House, Lviv 2021.

[14] Gunka V., Prysiazhnyi Yu., Hrynchuk Yu. et al.: Chem. Chem. Technol., 2021, 15, 443. https://doi.org/10.23939/chcht15.03.443

[15] Bratychak M., Gunka V., Prysiazhnyi Yu. et al.: Chem. Chem. Technol., 2021, 15, 274. https://doi.org/10.23939/chcht15.02.274 [16] Gunka V., Demchuk Y., Sidun I. et al.: Pet. Coal, 2020, 62, 420 .

[17] Bratychak M., Gunka V.: Khimia nafty i gazu. Vyd-vo Lviv Polytechnic, Lviv 2017.

[18] http://online.budstandart.com/ua/catalog/docpage.html?id doc $=79270$.

[19] Gunka V., Demchuk Y., Sidun I. et al.: Road Mater. Pavement Des., 2020. https://doi.org/10.1080/14680629.2020.1808518

[20] http://online.budstandart.com/ua/catalog/docpage.html?id_doc $=78305$

[21] Demchuk Y., Gunka V., Pyshyev S. et al.: Chem. Chem. Technol., 2020, 14, 251. https://doi.org/10.23939/chcht14.02.251

[22] Gun R. Neftianye Bitumy. Khimia, Moskva 1973.
[23] Moshchinskaia N.: Polimernye Materialy na Osnove Aromaticheskikh Uglevodorodov i Formaldegida. Monografia. Tekhnika, Kiev 1969

[24] Bratychak M., Gunka V.: Khimia Nafty i Gazu. Vyd-vo Lviv Polytechnic, Lviv 2020.

[25] Knop A., Sheib B.: Fenolnye Smoly i Materialy na ikh Osnovie. Khimia, Moskva 1983.

[26] Gutsuliak V., Nevskii V., Safronova A.: Arenformaldegidnye Oligomery. Nauka 1986.

[27] Nesmeianov A., Nesmeianov N.: Nachala Organicheskoi Khimii. T. 2. Moskva 1969.

[28] Kazitsyna L., Kupletskaia N.: Primenenie UF-, IK- i IaMRSpektroskopii v Organicheskoi Khimii. Vysshaia shkola. Moskva 1971

Received: December 18, 2020 / Revised: December 22, 2021 Accepted: February 12, 2021

\section{ОДЕРЖАННЯ БІТУМУ, МОДИФІКОВАНОГО НИЗЬКОМОЛЕКУЛЯРНИМИ ОРГАНІЧНИМИ СПОЛУКАМИ ІЗ НАФТОВИХ ЗАЛИШКІВ. 3. МОДИФІКУВАННЯ ГУДРОНУ ФОРМАЛЬДЕГІДОМ}

Анотація. Вивчена хімічна модифікація гудрону формальдегіду у вигляді 37\% водного розчину в присутності каталізаторів. Як каталізатори використані хлорна та сульфатна кислоти, гідроксид натрію та «кислі» гудрони. Досліджено вплив природи та кількості каталізатора, температури та тривалості процесу й співвідношення компонентів суміші на температуру розм'якшення, пенетрацію, температуру крихкості та зчеплення з поверхнею шебню. Структура модифікованого гудрону підтверджена ІЧ-спектроскопічними дослідженнями. Встановлено структурно-груповий склад модифікованих гудронів. Виходячи із толуолу та п-ксилолу, з використанням як каталізатор хлорної кислоти, синтезовані та охарактеризовані ІЧ-спектроскопічними дослідженнями ареноформальдегідні смоли. Запропоновано ймовірний хімізм прочесу модифікування гудрону формальдегідом.

Ключові слова: гудрон, формальдегід, неорганічні кислоти, «кислі» гудрони, ІЧ-спектроскопія, щебінь, температура розм'якшення, пенетрація, температура крихкості, зчеплення з поверхнею щебню, структурно-груповий аналіз, арено-формальдегідні смоли. 